Int. J. Dev. Biol. 52: 753-757 (2008)

doi: $10.1387 /$ ijdb.072543ta

\title{
The use of poly-L-lysine to facilitate examination of sperm entry into pelagic, non-adhesive fish eggs
}

\author{
TADASHI ANDOH ${ }^{1}$, TAKAHIRO MATSUBARA ${ }^{1}$, TATSUO HARUMI ${ }^{2}$ and RYUZO YANAGIMACHI ${ }^{3, *}$ \\ ${ }^{1}$ Hokkaido National Fisheries Research Institute, Fisheries Research Agency, Kushiro, Hokkaido, Japan, \\ ${ }^{2}$ Department of Anatomy, Asahikawa Medical College, Asahikawa, Japan and \\ ${ }^{3}$ Institute for Biogenesis Research, University of Hawaii Medical School, Honolulu, Hawaii, USA
}

\begin{abstract}
The fish egg is surrounded by a thick envelope called the chorion. The fertilizing spermatozoon enters the egg through a canal-like structure in the chorion, the micropyle. Examination of micropyle at fertilization is difficult if eggs are large and have no distinct landmarks surrounding the micropyle, or if they are positively buoyant in water. Eggs of many commercially important fishes (e.g., flounder, sea bream and eel) are buoyant in water or only slightly adhere to solid objects (e.g., sands, rock and water plants), which makes observation of spermatozoa at fertilization difficult. Here, we report that such eggs can be firmly attached to plastic and glass dishes that have been previously coated with poly-L-lysine. These adhering eggs can be fertilized and develop normally on the dishes. Observations of micropyles of three fish species, before and after sperm entry are presented.
\end{abstract}

KEY WORDS: fertilization, egg, sperm, micropyle, fish, poly-L-lysine

\section{Introduction}

The fish (teleost) egg is covered by a thick glycoprotein coat known as the chorion. Spermatozoa are able to enter the egg only through a canal-like structure in the chorion, the micropyle (Hart, 1990; Iwamatsu, 2000). Since spermatozoa of most fish swim very vigorously in water, it is generally assumed that the spermatozoa enter the micropyle by their random movement.

In 1953 Yanagimachi and Kanoh reported that herring spermatozoa, which were hardly motile in seawater, became very active upon contact with chorion in the micropyle region and enter the micropyle one by one in a chemotactic fashion, which is $\mathrm{Ca}^{2+}$ dependent. Suzuki (1958) noted that spermatozoa of bitterings (Acheilognathus and Rhodeus) were activated and aggregated near the micropyle of inseminated eggs. These studies suggest that sperm entry into the micropyle is not random, at least in these fish. The morphology of sperm entry in fish eggs was reported first by Yamamoto (1952) in the flounder, followed by many others in various fishes using both light and electron microscopes (Brummett and Dumont., 1979; Kudo, 1980; Iwamatsu and Ohta, 1981; Kobayashi and Yamamoto, 1981, 1987; Amanze and lyengar, 1990; Iwamatsu et al., 1991; Yanagimachi et al., 1992; Ishijima et al., 1993; Iwamatsu et al., 1993).
Eggs of some fish stick firmly to solid objects such as rocks, pebbles, sand and aquatic vegetation. Sperm entry into such eggs can be examined by first allowing them to stick to the bottom of a dish and observing the micropyle at $90^{\circ}$ to $180^{\circ}$ angle to the micropylar canal. Observation of the micropyle under high magnification enables details of sperm-egg interactions to be made. Eggs of many fish adhere to solid objects lightly or do not adhere at all. Eggs of many marine fish (such as some flounders and eels) are actually positively buoyant and float in seawater, which makes observation of sperm entry into eggs difficult, if not impossible. Poly-L-lysine (PLL), which was first used by Mazia et al. (1975) to stick various live cells (e.g., tissue cultured cells, amoebas and sea urchin eggs) to glass and dish surfaces, solved the problem. It enabled fish eggs to firmly attach to dishes so that we could readily examine micropyles during insemination.

\section{Results}

Table 1 shows some characteristics of the fish eggs utilized in this study. Eggs of all species but three (black plaice, huchen and

Abbreviations used in this paper: PLL, poly-L-lysine; PDL, poly-D-lysine.

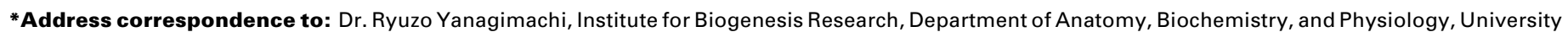
of Hawaii Medical School, 1960 East-West Road, Honolulu, Hawaii, 96822 USA. Tel: +1-808-956-8746. Fax: 1-808-956-7316. e-mail: yana@hawaii.edu
}

Published online: 11th June 2008. 


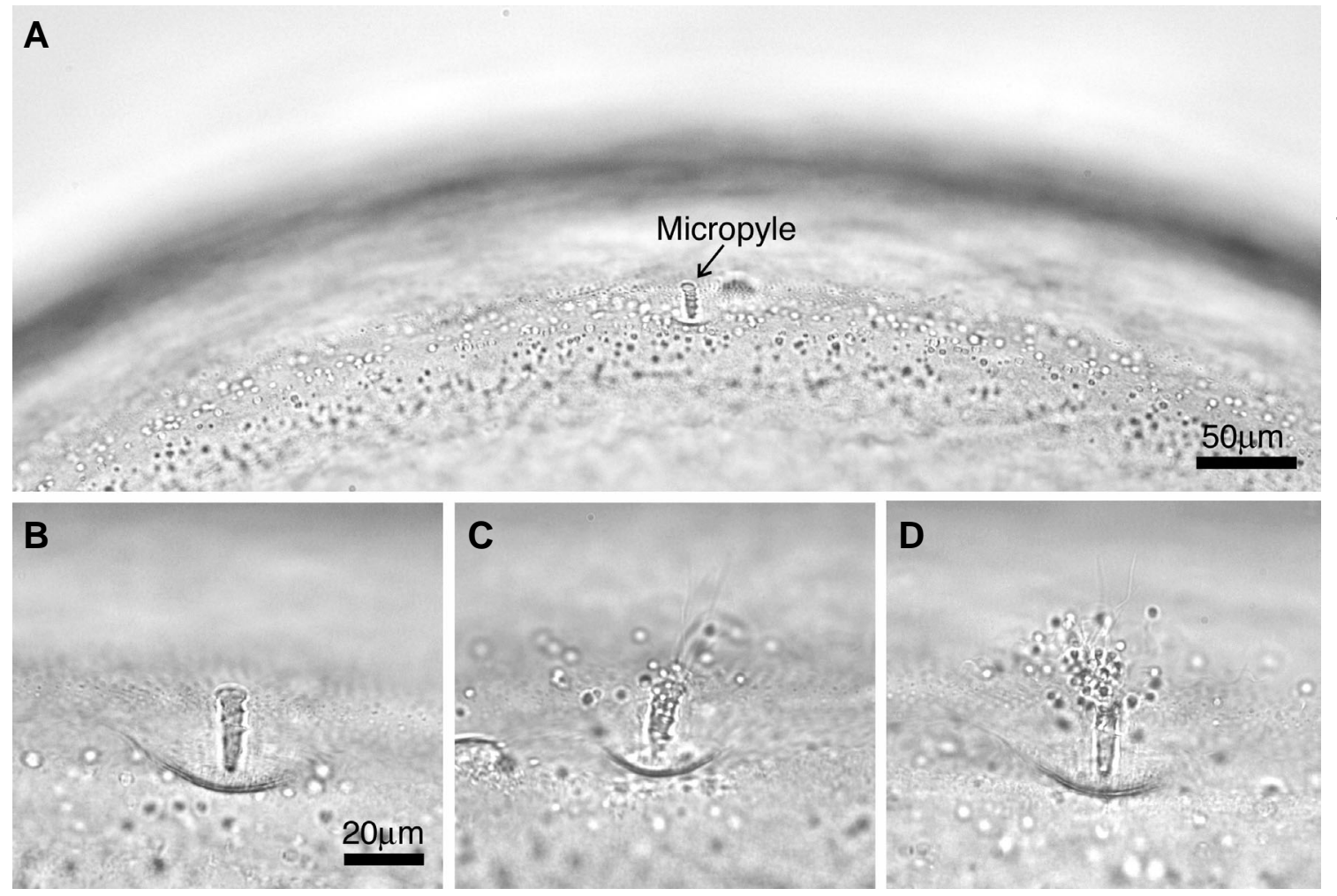

Fig. 1. Micropyle of barfin flounder egg. (A) A fully mature egg of the barfin flounder is large labout 1.7 $\mathrm{mm}$ in diameter). Its micropyle labout $20 \mu \mathrm{m}$ in length, arrow) appears very small. (B) A micropyle under higher magnification; the inner wall of the micropylar canal possesses a spiral configuration. (C) Micropyle of an egg about 20 sec after insemination; several spermatozoa are within the micropylar canal. The posterior part of sperm tails is outside the canal. The head of the first spermatozoon that entered the micropyle is already within the egg cytoplasm, but it is out of focus in this micrograph. (D) Micropyle of an egg about 2 min after insemination. When the egg is activated by the fertilizing spermatozoon, supernumerary spermatozoa within the micropylar canal are pushed out of the canal (most likely by cortical granule material) to join other spermatozoa aggregated around the opening of micropyle.

chum salmons) were non-adhesive and buoyant. Barfin flounder eggs were buoyant in seawater, but did firmly attach to PLLcoated dishes. Fig.1 A-B show micropyles of barfin flounder (Verasper moseri) eggs before insemination. Within several seconds following insemination, actively motile spermatozoa entered the micropyle one by one, filling the entire canal within $30 \mathrm{sec}$ to a few minutes (Fig. 1C), depending on sperm concentration and the quality of spermatozoa. Soon after the first (fertilizing) spermatozoon entered the egg cytoplasm, supernumerary spermato- zoa within the micropylar canal were pushed out of the canal to join spermatozoa aggregated around the opening of micropyle (Fig. 1D). When eggs were aged excessively within the ovarian cavity before collection or when spermatozoa were not fully mature, or excessively aged within the male's body, many or most spermatozoa failed to enter micropyles.

Eggs of the Japanese flounder (Hirame) (Palalichthys olivaceus) and the eel (Anguilla japonica) eggs were buoyant in seawater, but they firmly attached to PLL-coated dishes. Eel

TABLE 1

\section{SIZE OF EGGS AND MICROPYLES OF THE FISH STUDIED HERE}

\begin{tabular}{|c|c|c|c|c|c|c|}
\hline \multirow{3}{*}{ Species } & \multirow{3}{*}{$\begin{array}{c}\text { General } \\
\text { characteristics }\end{array}$} & \multicolumn{5}{|c|}{ Average } \\
\hline & & \multirow{2}{*}{ Diameter $(\mathrm{mm})$ of egg } & \multirow{2}{*}{$\begin{array}{c}\text { Thickness }(\mu \mathrm{m}) \text { of } \\
\text { chorion }\end{array}$} & \multicolumn{3}{|c|}{ Size $(\mu \mathrm{m})$ of micropyle } \\
\hline & & & & Length & Opening & Bottom \\
\hline $\begin{array}{l}\text { Barfin flounder } \\
\text { (Verasper moseri) }\end{array}$ & $\begin{array}{l}\text { Buoyant in SW } \\
\text { Non-adhesive }\end{array}$ & 1.7 & 15 & 20 & 10 & 3 \\
\hline $\begin{array}{l}\text { Black plaice } \\
\text { (Pleuronectes obscurus) }\end{array}$ & $\begin{array}{l}\text { Sedimentary in SW } \\
\text { Slightly adhesive }\end{array}$ & 0.8 & 15 & 22 & 6 & 1 \\
\hline $\begin{array}{l}\text { Starry flounder } \\
\text { (Platichthys stellatus) }\end{array}$ & $\begin{array}{l}\text { Buoyant in SW } \\
\text { Non-adhesive }\end{array}$ & 0.9 & 15 & 17 & 7 & 2 \\
\hline $\begin{array}{l}\text { Japanese flounder } \\
\text { (Paralichthys olivaceus) }\end{array}$ & $\begin{array}{l}\text { Buoyant in SW } \\
\text { Non-adhesive }\end{array}$ & 1.2 & 10 & 15 & 6 & 2 \\
\hline $\begin{array}{l}\text { Red sea bream } \\
\text { (Pagrus major) }\end{array}$ & $\begin{array}{l}\text { Buoyant in SW } \\
\text { Non-adhesive }\end{array}$ & 0.9 & - & 10 & 6 & 3 \\
\hline $\begin{array}{l}\text { Eel } \\
\text { (Anguilla japonica) }\end{array}$ & $\begin{array}{l}\text { Buoyant in SW } \\
\text { Non-adhesive }\end{array}$ & 1.0 & $1^{a}$ & 5 & 2 & 2 \\
\hline $\begin{array}{l}\text { Huchen salmon } \\
\text { (Hucho perryi) }\end{array}$ & $\begin{array}{l}\text { Sedimentary in FW } \\
\text { Slightly adhesive }\end{array}$ & 5.5 & - & - & - & - \\
\hline $\begin{array}{l}\text { Chum salmon } \\
\text { (Oncorhynchus keta) }\end{array}$ & $\begin{array}{l}\text { Sedimentary in FW } \\
\text { Slightly adhesive }\end{array}$ & 7.5 & - & 50 & 12 & 2 \\
\hline
\end{tabular}

a Chorion of eel egg is very thin except for its micropyle region. 
TABLE 2

ADHESION OF BARFIN FLOUNDER EGGS TO GLASS SLIDES COATED WITH POLY-AMINO ACIDS OF VARIOUS MOLECULAR WEIGHTS

\begin{tabular}{|c|c|c|c|c|c|}
\hline \multirow[b]{2}{*}{ Poly-amino acids } & \multirow[b]{2}{*}{ Mw of poly-amino acids $(\mathrm{kDa})^{1}$} & \multirow[b]{2}{*}{ No. of eggs used (No. of slides) } & \multicolumn{3}{|c|}{ Eggs left attached after washings ${ }^{2}$} \\
\hline & & & No. & $\%$ Range & $\%$ Mean \\
\hline \multirow[t]{5}{*}{ Poly-L-lysine } & 22 & $53(3)$ & 46 & $78-100$ & 87 \\
\hline & 83 & $58(3)$ & 34 & $89-100$ & 96 \\
\hline & 164 & $51(3)$ & 50 & $94-100$ & 98 \\
\hline & 350 & $65(3)$ & 65 & 100 & 100 \\
\hline & 575 & $42(3)$ & 42 & 100 & 100 \\
\hline Poly-D-lysine & 481 & $110(3)$ & 110 & 100 & 100 \\
\hline Poly-L-aspartic acid & 32 & $71(3)$ & 19 & $17-38$ & 26 \\
\hline Poly-L-glutamic acid & 56 & $76(3)$ & 3 & $0-9$ & 3 \\
\hline
\end{tabular}

${ }^{1} \mathrm{Mw}$ was measured by viscosity. ${ }^{2}$ Washings were performed using a $1 \mathrm{ml}$ pipette.

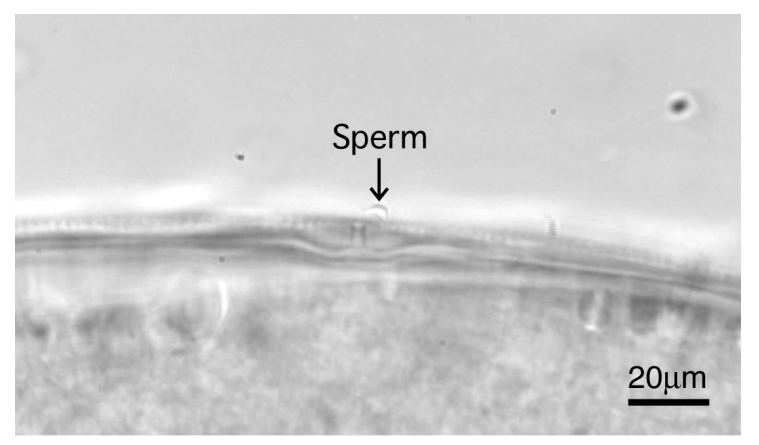

Fig. 2. An eel spermatozoon about to enter the micropyle of an eel egg. Due to its unusual axoneme organization $(9+0)$, eel spermatozoon swim in a "jerking" fashion. This sperm (arrow) is about to enter the micropyle (side view). The sperm tail is out of focus.

spermatozoa about to enter the micropyles were observed and shown in Fig. 2. Starry flounder (Platichthys stellatus) eggs were also buoyant in seawater. They did not firmly attach to PLL-coated dishes when the dish was filled with full strength seawater, but they did when the dish was filled with $1 / 2$ diluted (distilled water) seawater (Table 3). Sperm entry into micropyles (fertilization) could be observed in this $50 \%$ seawater (Fig. 3 A,B). Eggs of the huchen salmon (Huchoperry), chum salmon (Oncorhychus keta) and black plaice (Pleuronectes obscurus) were negatively buoyant and sank to the bottom of dishes with fresh water (salmon) or seawater (black plaice), adhering lightly to dishes. These eggs
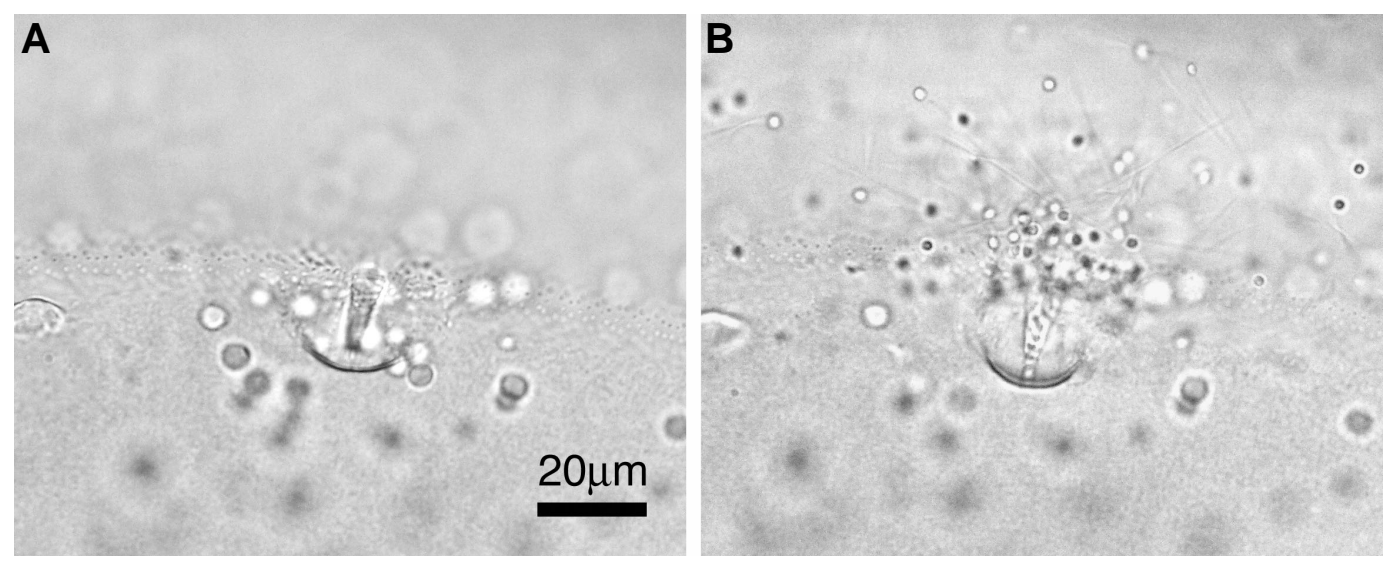

Fig. 3. Micropyle of starry flounder egg. (A) Before insemination. (B) About 1 min after insemination with the micropylar canal filled with spermatozoa.
TABLE 3

\section{ADHESION OF STARRY FLOUNDER EGGS TO GLASS SLIDES COATED WITH POLY-L-LYSINE $(\mathrm{MW}=513 \mathrm{kDa})$}

\begin{tabular}{ccccc} 
& \multirow{2}{*}{$\begin{array}{c}\text { No. of eggs used } \\
\text { \% Seawater }\end{array}$} & \multicolumn{3}{c}{ Eggs remained attached to slides after washing } \\
\cline { 3 - 5 } (No. of slides) & No. & $\%$ Range & $\%$ Mean \\
\hline 100 & $40(1)$ & 23 & 58 & 58 \\
50 & $209(3)$ & 208 & $99-100$ & 100 \\
\hline
\end{tabular}

adhered firmly to PLL-coated dishes. Of all the eggs we tested only those of the red sea bream (Pagrus major) failed to adhere to PLL-coated dish.

A series of experiments using barfin flounder eggs showed that PLL worked regardless of the molecular weight, but was more effective with increasing molecular weight (Table 2). Poly-Dlysine (PDL) was also as effective as PLL, whereas poly-Laspartic acid and poly-L-glutamic acid were not (Table 2).

\section{Discussion}

In fish, the sperm entry point into the egg is restricted to the micropylar canal. Although more than two spermatozoa may enter the opening of the micropyle simultaneously, only the one that first advances to the lower portion of the micropyle is able to enter (fuse with) the egg plasma membrane as the diameter of the lower portion and the exit point of the micropyle is identical with the diameter of sperm head. Normally, the second and subsequent spermatozoa are pushed out of the micropyle after exocytosis of cortical granules (Yamamoto, 1952, Yanagimachi and Kanoh, 1953; Kobayashi and Yamamoto, 1987) and the lower portion of micropylar canal closes, perhaps by proteolytic action of cortical granule materials (Iwamatsu et al., 1997).

There is no concrete evidence that fish eggs or micro- 
pyles themselves "attract" spermatozoa from a distance. Rather, sperm-egg encounters seems to be a random event. Yanagimachi et al. (1992) witnessed that salmon and trout spermatozoa swam actively in water and come into contact with chorion surface apparently by random movement. Those sperm that collided with chorion moved along chorion surface in a thigmotactic fashion. They were not directed to the micropyle, but once they came into contact with the opening ("vestibule") of the micropyle, they entered the micropyle immediately or after abrupt change in their path. This occurred only when the medium contained a sufficient amount of $\mathrm{Ca}^{2+}$ (Yanagimachi et al., 1992). The suggestion from these observations was that spermatozoa were guided into the micropyle by a factor (or substance) bound to the chorion immediately surrounding the opening of micropyle, as well as along the miropylar canal. This hypothetical factor, called "sperm-guidance factor" (Yanagimachi et al., 1992) or "micropylar sperm guidance factor" (MSGF), probably exists in all fish species. Herring eggs possess a sperm motility initiation factor (SMIF) around the micropyle, which brings motionless spermatozoa to a motile state (Griffin et al., 1996). In herring, SMIF activates spermatozoa first, then MSGF may direct motile spermatozoa into the micropyle. It is possible however that or SMIF plays two distinct roles: motility initiation and micropylar guidance. In other fish, only MSGF is needed as their spermatozoa are already active in water. The origin of SMIF and MSGF is not clear, but they are most likely the products of a giant micropylar cell which contributes to the formation of micropylar canal. The structural relationship between the micropylar cells and the micropylar canal has been described in details in the herring, salmon and medaka (Ohta and Takano, 1982; Kobayashi and Yamamoto, 1985; Kawashima and Iwamatsu, 1994). Follicular cells around the micropylar cells may also contribute to the production of SMIF which is located around the outer opening of the herring egg micropyle (Griffin et al., 1996). Herring SMIF was previously isolated and identified as a $105 \mathrm{kD}$ glycoprotein (Pillai et al., 1993). Its receptor(s) is in the midpiece region of the spermatozoon (Griffin et al., 1996). At present, nothing is known about the chemical nature of the MSGF. To isolate MSGF, a large number of mature unfertilized eggs would be needed. Any fish with a vast quantity of fully mature eggs could be used. It is important to ascertain whether eggs remained undamaged and whether MSGF is absent from the micropylar region following the extraction. PLL that allows eggs to firmly attach to dishes or slides facilitates this step of the effort.

During the course of this study, we experienced difficulty in attaching starry founder eggs to PLL-coated dish. When the dish was filled with natural seawater, the eggs floated in the water. Apparently, the buoyancy of the eggs surpassed the adhesion force between eggs and the PLL-coated dish. When $50 \%$ seawater was used instead of natural seawater, all of the eggs remained firmly attached to the PLL-coated dish. Specific gravities of eggs and water must be taken into consideration when buoyant eggs are to be attached to dishes or glass. As starry flounder eggs can be fertilized and develop in $50 \%$ seawater, this does not pose any problems for this species. Eggs of some other marine fish may not be able to tolerate diluted seawater. Red sea bream eggs were highly buoyant and were unable to adhere to a PLL-coated dishes. Whether they were able to adhere to PLL-coated dish with $50 \%$ seawater and whether fertilization could take place in diluted seawater were not tested in the present study.
When plastic dishes were used, only those with hydrophilic treatment allowed eggs to adhere to them after PLL treatment. Non-treated polystyrene dish repelled water and eggs. Positively charged PLL on dish surfaces must attract negatively charged proteins or glycoproteins such as fish egg chorion. Increasing molecular weight of PLL resulted in stronger adhesion of eggs to dishes (Table 2), suggesting that the amount of positive charge per PLL molecule is a determining factor of egg adhesion to dishes. Poly-D-lysine was as effective as PLL, while negatively charged poly-amino acids were not (Table 2). This suggests that the charge rather than tertiary structure of poly-amino acids is important for egg adhesion to dishes.

\section{Materials and Methods}

\section{Gametes}

Mature eggs and spermatozoa were collected from animals in the peak of their spawning seasons by gentle squeezing their abdomen at Hokkaido National Fisheries Research Institute, Fisheries Research Agency (FRA) in Kushiro and Akkeshi (barfin flounder, black plaice, starry flounder), National Research Institute of Aquaculture, FRA, in Nansei, Ise (Japanese flounder, red sea bream and eel), Faculty of Fisheries, Hokkaido University in Hakodate (huchen salmon), or Tsurui salmon hatchery station, FRA, in Tsurui (chum salmon). Eggs (in coelomic fluid) and spermatozoa (in seminal plasma) from different individuals were stored separately in covered plastic dishes or in centrifuge tubes at $0-4^{\circ} \mathrm{C}$.

\section{Preparation of poly-L-lysine-coated slides or dishes}

Poly-L-lysine (PLL) of various molecular weights (22 - $575 \mathrm{kDa}$; either hydrochlorides or hydrobromides), poly D-lysine (481 kDa), poly-L-aspartic acid $(32 \mathrm{kDa})$ and poly-L-glutamic acid $(56 \mathrm{kDa})$ were purchased from Sigma (St. Louis, MO, USA). Each was dissolved in distilled water at the concentration of $1 \mathrm{mg} / \mathrm{ml}(0.1 \%)$ and maintained at $4^{\circ} \mathrm{C}$ for up to one month before use. Most experiments were performed using PLL. The surface of a pre-cleaned glass slide $(76 \times 26 \mathrm{~mm})$ or the bottom of a glass Petri-dish $(60 \times 13 \mathrm{~mm})$ or a polystyrene dish $(60 \times 15 \mathrm{~mm}$; cat. no. \# 353002; Becton Dickinson Labware, Franklin Lakes, NJ, USA) were covered with $\sim 5 \mathrm{ml}$ of PLL solution. After rocking the dish for $\sim 10 \mathrm{~s}$ at room temperature, PLL solution was removed using a pipette. PLL-treated slides and dishes were dried in air for several hours or by blowing lukewarm air using a hair-drier. They were used with or without rinsing with seawater. PLL solution could be used repeatedly to treat many slides and dishes

\section{Adhesion of eggs to PLL-coated dish}

Eggs of the barfin flounder and many other marine fish are buoyant or suspended in seawater. To adhere them to dishes, a group of eggs (20100 ) from the coelomic fluid or from a drop of flounder Ringer solution (Hirano et al., 1971) was placed at the center of a PLL-coated dish. Using a fine pipette, the coelomic fluid (or Ringer) around the eggs was carefully removed. This caused the eggs to "flattened" and to increase the contact area between egg's chorion and PLL-coated dish. When seawater was then added to the dish, eggs remained attached to the bottom of the dish. We usually washed the eggs several times with fresh seawater before use. PLL-coated dishes could be used repeatedly by removing eggs by vigorous jets of running water or by gently wiping off the eggs using a tissue paper followed by rinsing with tap water and distilled water.

\section{Examination of eggs before and after insemination}

Fish eggs vary greatly in their size according to species $(0.7-10 \mathrm{~mm}$ in diameter), but spermatozoa are not. The sperm head of most fish is 1 $3 \mu \mathrm{m}$ in diameter and the tail is $20-50 \mu \mathrm{m}$ in length. Finding a micropyle in the chorion and examining entry of small spermatozoa into a micropyle 
could be difficult if the egg is perfectly round and the chorion around the micropyle does not have any distinct depression or grooves running towards the micropyle as observed in eggs of the rosy barb (Amanze and lyengar, 1990; Iwamatsu, 2000). Although the barfin flounder egg is large (1.7-1.8 $\mathrm{mm}$ in diameter) and does not have any distinct "landmarks" around the micropyle, it can be readily located under low magnification (10x, UPlanFLN, Olympus) of microscope with the ordinary transmission light due to transparent egg cytoplasm. We searched for micropyles of eggs one by one after attaching eggs to a PLL-coated dish with seawater. The water should not be excessively deep (approximately $\sim 5 \mathrm{~mm}$ ). We commonly used an ordinary low magnification objective (10x) to locate the micropyle. After selecting an egg with the micropyle in a proper (selected) angle of examination, the objective was switched to a water-immersion objective (20 x, $40 \times$ LUMPlanFI, Olympus, and 40x, Zeiss). By properly adjusting the intensity of light, diaphragm and the condenser position, the micropyle could be clearly observed. Sperm suspension was prepared by diluting a small amount (e.g., $5 \mu \mathrm{l}$ ) of "milt" with seawater or suspending spermatozoa in isotonic Ringer's solution or $1 / 3$ diluted seawater. Flounder spermatozoa in the milt, Ringer and or the diluted seawater were motionless, however, they became actively motile upon dilution with natural seawater. Spermatozoa approaching and entering the micropyle could be examined continuously. Salmon spermatozoa differed in that they could move actively in Ringer's solution.

\section{Acknowledgements}

This study was supported by a grant from the Fisheries Research Agency (Japan). Eggs and sperm were kindly provided by Mr. Takashi Ichikawa (Hokkaido National Fisheries Research Institute), Mr. Shigenori. Suzuki (Minamiizu Station, National Center for Stock Enhancement), Dr. Hideki Tanaka and Dr. Koichiro Gen (National Institute of Aquaculture) and Dr. Etsuro Yamaha (Hokkaido University). We thank to Dr. G. N. Cherr, University of California, Davis, for critical reading the manuscript. Thanks also to Mrs. Charlotte Oser for editing the original manuscript.

\section{References}

AMANZE, D. and IYENGAR,A. (1990). The micropyle: A sperm guidance system in teleost fish fertilization. Development 19: 495-500.

BRUMMETT, A.R. and DUMONT, J. (1979). Initial stage of sperm penetration into the egg of Fundulus heteroclitus. J. Exp. Zool. 210: 417-434.

GRIFFIN, F.J., VINES, C.A., PILLAI, M.C., YANAGIMACHI, R. and CHERR, G.N (1996). Sperm motility initiation factor is a minor component of the Pacific herring egg chorion. Dev. Growth Diff. 38: 193-202.

HART, N.H. (1990). Fertilization in teleost fishes: Mechanisms of sperm-egg interactions. Int. J. Cytol. 121: 1-66.

HIRANO, T., JOHNSON, D.W. and BERN, H.A. (1971). Control of water movement in flounder urinary bladder by prolactin. Nature 230: 469-470.

ISHIJIMA, S., HAMAGUCHI, Y. and IWAMATSU, T. (1993). Sperm behavior in the micropyle of the medaka egg. Zool. Sci. (Tokyo) 10:179-182.

IWAMATSU, T. (2000). Fertilization in fishes. In: Fertilization in Protozoa and Metazoan (eds. J.J. Tarin and A. Cano), pp. 89-145. Springer-Verlag: Berlin/ Heidelberg.

IWAMATSU, T. and OHTA, T. (1981). Scanning electron microscopic observations on sperm penetration in teleost fish. J. Exp. Zool. 218: 261-277.

IWAMATSU, T., ONITAKE,K., YOSHIMOTO, Y. and HIRAMOTO, Y. (1991). Time sequence of early events in fertilization in the medaka egg. Dev. Growth Diff. 33: 479-490.

IWAMATSU,T., ISHIJIMA, S. and NAKANISHI, S. (1993). Movement of spermatozoa and changes in micropyles during fertilization in medaka eggs. J. Exp. Zool. 266: 57-64.

IWAMATSU, T., YOSHIZAKI, N. and SHIBATA, Y. (1997). Changes in the chorion and sperm entry into the micropyle during fertilization in teleost fish, Oryzia latipes. Dev. Growth Diff. 39: 33-41.

KAWASHIMA, S. and IWAMATSU, T. (1994). Ultrastructural changes in micropyle and granulose cells during in vitromaturation in the medaka, Oryzias latipes. J. Exp. Zool. 270: 547-556.

KOBAYASHI, W. and YAMAMOTO, T.S. (1981). Fine structure of the micropylar apparatus of the chum-salmon eggs, with a discussion of the mechanism for blocking polyspermy. J. Exp. Zool. 217: 265-275.

KOBAYASHI, W. and YAMAMOTO, T.S. (1985). Fine structure of the micropylar cell and its change during oocyte maturation in the chum salmon, Oncorhynchus keta. J. Morph. 184: 263-276.

KOBAYASHI, W. and YAMAMOTO, T.S. (1987). Light and electron microscopic observations of sperm entry in the chum salmon egg. J. Exp. Zool.243:311-322.

KUDO, S. (1980). Sperm penetration and the formation of a fertilization cone in the common carp egg. Dev. Growth Diff. 22: 403-414.

MAZIA, D., SCHATTEN, G. and SALE, W. (1975). Adhesion of cells to surfaces coated with polylysine. J. Cell Biol. 66: 198-200.

OHTA, H. and TAKANO, K. (1982). Ultrastructure of the micropylar cell in the periovulatory follicles of Pacific herring, Clupea pallasi. Bull. Fac. Fish. Hokkaido Univ. 33: 57-66.

PILLAI, M. C., SHIELD. T. S., YANAGIMACHI, R. and CHERR, G.N. (1993). Isolation and partial characterization of the sperm motility initiation factor from eggs of the Pacific herring. J. Exp. Zool. 265: 336-342.

SUZUKI, R. (1958). Sperm activation and aggregation during fertilization in some fishes. I. Behavior of spermatozoa around the micropyle. Embryologia 4: 93102.

YAMAMOTO, K. (1952). Studies on the fertilization of the egg of the flounder. II. The morphological structure of the micropyle and its behavior in response to sperm entry. Cytologia 16: 302-306.

YANAGIMACHI, R. and KANOH, Y. (1953). Manner of sperm entry in the herring egg, with special reference to the role of calcium in fertilization. J. Fac. Sci. Hokkaido Univ. Ser. 6 (Zool.) 11: 487-498.

YANAGIMACHI, R., CHERR, G.N., PILLAI, M.C. and BALDWIN, J.D. (1992). Factors controlling sperm entry into the micropyles of salmonid and herring eggs. Dev. Growth Diff. 34:447-461. 


\section{Related, previously published Int. J. Dev. Biol. articles}

See our recent Special Issue Developmental Biology in Poland edited by Tarkowski, Maleszewski and Kloc at: http://www.ijdb.ehu.es/web/contents.php?vol=52\&issue=2-3

See our recent Special Issue Ear Development edited by Fernando Giraldez and Bernd Fritzsch at: http://www.ijdb.ehu.es/web/contents.php?vol=51\&issue=6-7

Regionalized calcium signaling in zebrafish fertilization Dipika Sharma and William H. Kinsey Int. J. Dev. Biol. (2008) 52: 561-570

Expression of protocadherin 18 in the CNS and pharyngeal arches of zebrafish embryos Fumitaka Kubota, Tohru Murakami, Yuki Tajika and Hiroshi Yorifuji Int. J. Dev. Biol. (2008) 52: 397-405

Cadherin-6 is required for zebrafish nephrogenesis during early development Fumitaka Kubota, Tohru Murakami, Kenji Mogi and Hiroshi Yorifuji Int. J. Dev. Biol. (2007) 51: 123-129

Skin development in bony fish with particular emphasis on collagen deposition in the dermis of the zebrafish (Danio rerio). Dominique Le Guellec, Ghislaine Morvan-Dubois and Jean-Yves Sire Int. J. Dev. Biol. (2004) 48: 217-231

Fertilization triggers activation of Fyn kinase in the zebrafish egg. W Wu and W H Kinsey Int. J. Dev. Biol. (2000) 44: 837-841

Intestinal fatty acid binding protein gene expression reveals the cephalocaudal patterning during zebrafish gut morphogenesis.

M André, S Ando, C Ballagny, M Durliat, G Poupard, C Briançon and P J Babin Int. J. Dev. Biol. (2000) 44: 249-252

Egg-jelly signal molecules for triggering the acrosome reaction in starfish spermatozoa.

M Hoshi, T Nishigaki, A Ushiyama, T Okinaga, K Chiba and M Matsumoto Int. J. Dev. Biol. (1994) 38: 167-174

Electrically fused-egg induction and its development in the goldfish, Carassius auratus.

E Yamaha and F Yamazaki

Int. J. Dev. Biol. (1993) 37: 291-298

Mitochondrial DNA content and mitochondrial gene transcriptional activities in the early development of loach and goldfish.

G Wang and S Yan

Int. J. Dev. Biol. (1992) 36: 477-482

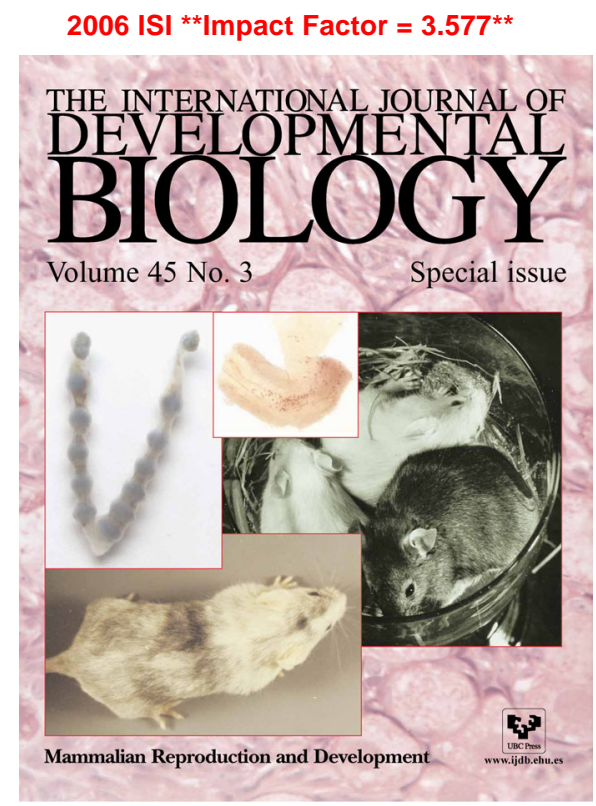

